\title{
On Financial Markets and Financial Regulation
}

\section{Jeffrey Jarrett*}

Department of Management Science, University of Rhode Island, USA

Previous research by many financial economists indicates that the behavior of financial markets whether in the United States, Europe, South America, Canada and many other places are interrelated. The financial markets are also not without imperfections and rapid changes in some markets have serious effects on the velocity of change in other markets. Profound changes make markets in the short run unstable and affect the lifetime earnings of those who invest and those who rely on stability in financial to plan and execute their lifetime plans; including funding home purchases, living costs, College tuition, retirement and the many other factors that a person's wealth must fund. In essence, financial markets should allow for a even playing field for all to earn income without giving a few the ability to earn more by imperfect economic and law which enable some to earn huge incomes while preventing others from earning decent incomes from investments.

Others argue that regulation of financial markets even for those that not economically efficient that it is too costly and in the end protect those who are being regulated rather than those who need an even playing field. This argument goes much of the research emanating from those who study imperfections in stock and other financial markets exemplified by recent studies of the financial crises in the United States, Asia especially China and Japan and the various European nations. Regulation is necessary to protect the investor in a manner similar to regulations in insure that depositors in saving and commercial banks are regulated. Similarly, retirement planning requires regulation to exclude unscrupulous tactics to deprive retirees from accessing the funds that they have invested over their income earning lifetime. Life insurance is another way of saving and retirement planning that is also regulated to protect both the investors in life insurance and their beneficiaries from the unscrupulous. No matter how the United States de-regulated the Airlines Industry, we still have tight and important regulations for Airline Safety and programs to diminish terrorism on flights and in airports. Shipping lines, railroad and even ground transportation art regulated for safety.

Enterprise that fail can cause great shocks to financial markets which turn into economic contractions causing loss of great wealth, unemployment, business stagnation and enormous damage to all parts of the economy. Some firms when they default create panics which in turn cause more panic in financial markets whose economic viability is related to the panic in the original failing economy. These firms cannot be allowed to fail if we are to stabilize financial markets and prevent enormous dislocations in other markets. We have seen in recent years that such dislocations are lasting and the direct result of not regulating and financial assets to keep them from becoming toxic.

There is certain time when assets owned and operated by governments should not be privatized. We cannot expect private initiative to operate and often build a Hoover Dam, George Washington Bridge, the New York and San Francisco Rapid Transit systems and similar government activities that simply would not exist if left only to private means. Throughout the United Sates and other nations there, are similar huge projects that could not be created without the participation of government. The Panama Canal was not built by a steamship company and General Electric did not send Astronauts to the Moon. Some enterprises are best left to government.
Opponents of financial regulation rely on beliefs that include the notion that in the long run economic efficiencies will create free markets and this will lead to efficient allocation of scarce resources. That is, banks fail, manufacturing firms disappear and progress continues. However, financial market studies indicate that the markets are not efficient in both the weak form and strong form of the efficient markets hypothesis (EMH). Arguing that in the long run those markets operate according to the EMH has a serious weakness. The long run solution does not occur in any historical study of the financial markets. These studies indicate that markets are inefficient in historical periods examined.

Can facilities progress economically and be innovative to produce solutions to many medical problems? Yes, if they are given the chance to study and produce solutions without certain regulations of their activities. We have much more regulation of stem cell research than we need since government (because of political motivations) satisfies those who are against progress. Government should deregulate those imperfect laws that prevent research and encourage those who do the research. Some who are against stem cell research claim in other areas tend to be in favor of de-regulated (free) markets. The irony is great.

If laws are imperfect, some argue that there will always be a way around these laws. This is true, but it is not a sound argument against regulation of financial markets. The legal system is a growing. Laws are interpreted in light of changes in the economy and ecology of humans. They need to be changed to fit the world we live in. If laws are stagnant and imperfect, there will inevitably by economic inefficiencies. However, this is not an argument which should apply to producing efficient markets and a sound financial system. People will lose their wealth if they operate by making unwise decisions. This will occur in both regulated and unregulated markets. However, in regulated losses should be "fair and equitable."

Financial markets are important and crucial in an economy. We as researchers in financial should work tirelessly towards the goal of fair and equitable markets so that investors have the opportunity to create wealth and satisfies their desires. No one should have the opportunity to create wealth and prevent others from so doing.

*Corresponding author: Jeffrey Jarrett, Department of Management Science, University of Rhode Island, USA, Tel: 1-401-874-4169; Fax: 1-401-874-4312 E-mail: jejarrett@mail.uri.edu

Received January 30, 2012; Accepted February 01, 2012; Published February 04, 2012

Citation: Jarrett J (2012) On Financial Markets and Financial Regulation. J Bus \& Fin Aff 1:e104. doi:10.4172/2167-0234.1000e104

Copyright: (C 2012 Jarrett $\mathrm{J}$. This is an open-access article distributed under the terms of the Creative Commons Attribution License, which permits unrestricted use, distribution, and reproduction in any medium, provided the original author and source are credited. 